\title{
Tri-ionizable calix[4]arene ligands: synthesis and lanthanide ion complexation
}

\author{
Fernando A. Fernandez, ${ }^{\mathrm{a} *}$ Richard A. Bartsch, ${ }^{\mathrm{b}}$ Françoise Arnaud-Neu, ${ }^{\mathrm{c}}$ \\ Véronique Hubscher-Bruder, ${ }^{\mathrm{c}}$ and Sylvie Michel $^{\mathrm{c}}$ \\ ${ }^{a}$ Department of Chemistry, York University, 4700 Keele St, Toronto, ON, M3J 1P3, Canada \\ ${ }^{b}$ Department of Chemistry and Biochemistry, Texas Tech University, Lubbock, \\ TX 79409-1061, USA \\ ${ }^{c} I P H C-D S A, U D S, C N R S, 25$ rue Becquerel, F-67087 Strasbourg, France \\ E-mail: fernandf2000@yahoo.com
}

\begin{abstract}
New proton-ionizable $p$-tert-butylcalix-4-arene ligands with three $\mathrm{N}$-(X)sulfonyl oxyacetamide groups and one methoxy group on the lower rim capable of forming electroneutral complexes with trivalent lanthanide ions are synthesized. Variation of the electron-withdrawing ability of $\mathrm{X}$ ( $\mathrm{Me}, \mathrm{Ph}, \mathrm{C}_{6} \mathrm{H}_{4}-4-\mathrm{NO}_{2}, \mathrm{CF}_{3}$ ) is used to tune the ligand acidity. Conformations of the ligands in $\mathrm{CDCl}_{3}$ are investigated by variable temperature NMR spectroscopy. By potentiometric titration, complexation of $\mathrm{La}^{3+}, \mathrm{Eu}^{3+}$, and $\mathrm{Yb}^{3+}$ by the tri-ionizable complexing agents in $\mathrm{MeOH}$ is probed.
\end{abstract}

Keywords: Proton-ionizable calixarene, lanthanide ion complexation, potentiometric titration

\section{Introduction}

Calixarene scaffolds are frequently employed in the development of new ligands for selective metal ion recognition and separation. ${ }^{1-9}$ By attachment of functional groups to the lower rim of calix[4]arene, new metal ion complexing agents with high selectivity have been discovered. Of special interest in our laboratories are calix[4] arenes with pendent proton-ionizable groups ${ }^{10,11}$ since these ligands generally provide stronger binding of cationic species than their neutral analogues. Also when the number of acidic sites in the side arms of the ligand matches the charge on the metal ion an electroneutral complex is formed. For a solvent extraction process, this eliminates the need to transport one or more anions from an aqueous phase into the organic diluent, thereby markedly enhancing metal ion extraction efficiency. This is especially important when highly hydrophilic aqueous phase anions of chloride, nitrate, and sulfate are involved. For example, we have found that lower-rim 1,3-disubstituted $N$-(X)sulfonyl tert-butylcalix-[4] arenecarboxamides 1-4 (Figure 1) exhibit efficient and highly selective extraction of heavy metal 
species $\mathrm{Pb}^{2+}$ and $\mathrm{Hg}^{2+} \cdot{ }^{10-11}$ The acidity of the ligand was "tuned" by variation of the electronwithdrawing ability of $\mathrm{X}^{12}$

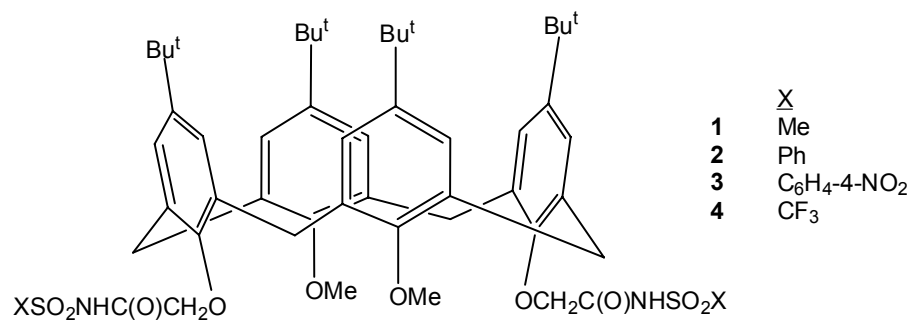

Figure 1. Structures of previously studied di-ionizable $p$-tert-butylcalix[4]arene ligands.

We now turn our attention to complexing agents for trivalent lanthanide ions. Herein we report the synthesis of tri-ionizable $p$-tert-butylcalix[4]arene analogues 5-8 (Figure 2) and the initial evaluation of their complexation of selected trivalent lanthanide ions in $\mathrm{MeOH}$ by potentiometric titration. In this series of ligands, variation of the electron-withdrawing properties of X should change the acidity. Some conformational flexibility is anticipated due to the small methyl group that is used to cap the fourth phenolic oxygens.

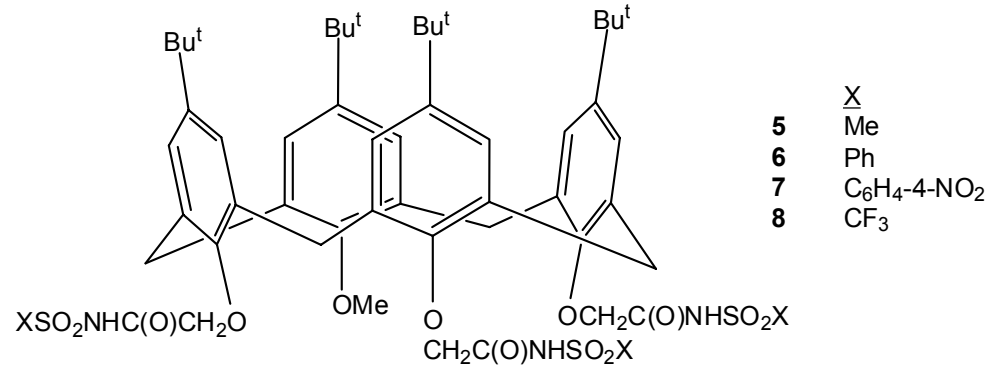

Figure 2. Structures of new tri-ionizable $p$-tert-butylcalix[4]arene ligands.

\section{Results and Discussion}

\section{Ligand synthesis}

The synthetic route to the tri-ionizable calix[4] arene ligands 5-8 is shown in Scheme 1.

The initial attempt to monomethylate $p$-tert-butylcalix[4]arene 9 by its reaction with $\mathrm{K}_{2} \mathrm{CO}_{3}$ and $\mathrm{MeI}$ in $\mathrm{MeCN}$ at reflux ${ }^{13}$ gave mostly dimethylated product. Subsequently, the monomethyl ether 10 was realized in $60 \%$ yield by reaction of 9 with $\mathrm{CsF}$ and MeI in DMF at $40{ }^{\circ} \mathrm{C} .{ }^{13}$ The reported reaction of $\mathbf{1 0}$ with $\mathrm{K}_{2} \mathrm{CO}_{3}$ and ethyl bromoacetate in $\mathrm{MeCN}$ at reflux ${ }^{14}$ gave a $50 \%$ yield of triester 11. The IR spectrum of $\mathbf{1 1}$ showed two different carbonyl absorptions at 1741 and $1758 \mathrm{~cm}^{-1}$. Basic hydrolysis of triester 11 followed by acidification gave an $80 \%$ yield of 
tri(carboxylic acid) 12. Refluxing $\mathbf{1 2}$ with an excess of oxalyl in benzene gave tri(acid chloride) 13, which was used directly in the next step. In the IR spectrum of 13, the carbonyl and O-H stretching absorptions of $\mathbf{1 2}$ were replaced by a new carbonyl absorption at $1809 \mathrm{~cm}^{-1}$. From reactions of tri(acid chloride) $\mathbf{1 3}$ with the sodium salts of commercially available sulfonamides in THF, the tri-ionizable calix[4] arene ligands 5-8 were obtained in 52-65\% overall yields from tri(carboxylic acid) 12. Structures of new compounds 5-8 and 12 were verified by IR and NMR spectroscopy and confirmed by combustion analysis.

Attachment of groups larger than ethyl to the lower-rim oxygens of calix[4]arenes restricts oxygen-through-the-annulus rotation of the arene units. ${ }^{14}$ Therefore, ligands 5-8 have one mobile arene unit with two possible limiting conformations: cone and partial cone (paco). The broadened signals observed in the ${ }^{1} \mathrm{H}-\mathrm{NMR}$ spectra for the $\mathrm{OCH}_{3}$ group (e.g., at $3.52 \mathrm{ppm}$ in 7) indicate that conformational interconversions are taking place in $\mathrm{CDCl}_{3}$.
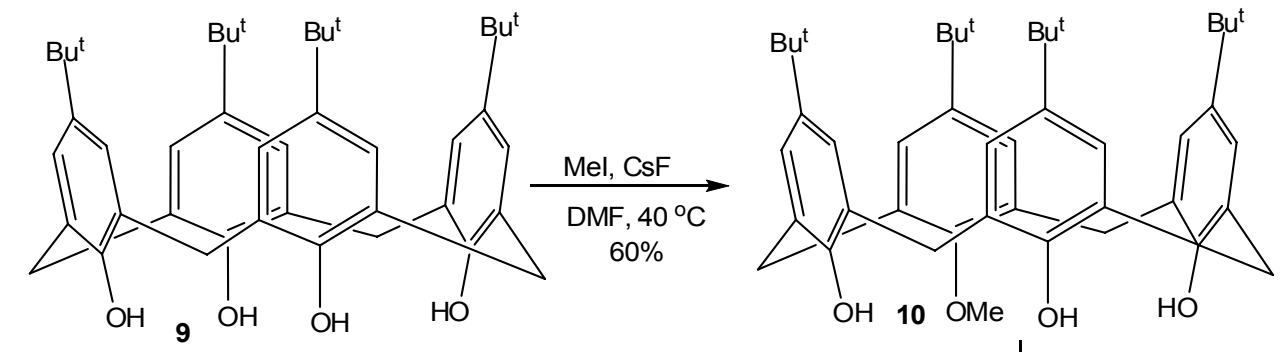

$\mathrm{BrCH}_{2} \mathrm{CO}_{2} \mathrm{Et}, \mathrm{K}_{2} \mathrm{CO}_{3} \downarrow \mathrm{MeCN}$, reflux, 50\%
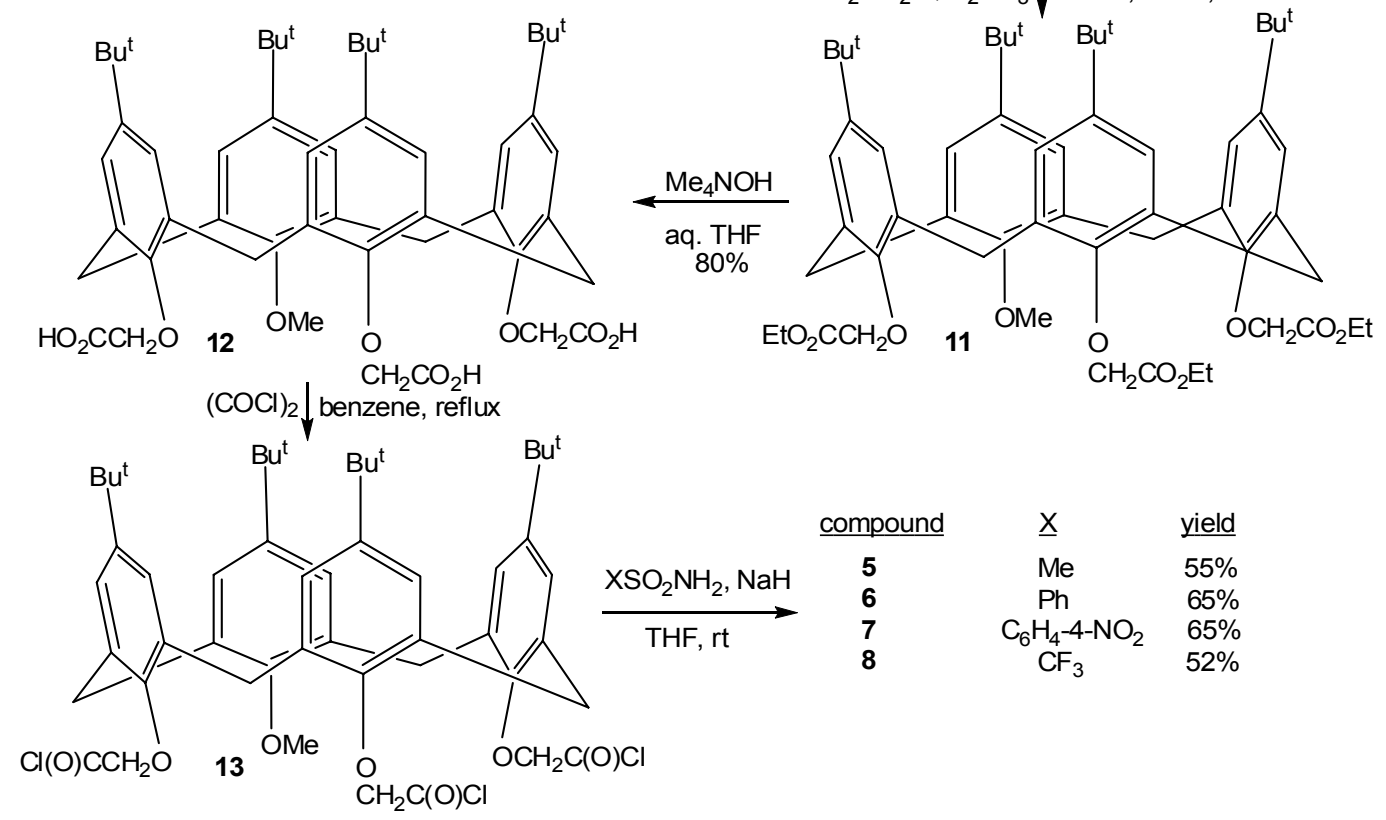

Scheme 1. Synthesis of tri-ionizable $p$-tert-butylcalix[4]arene ligands 5-8. 

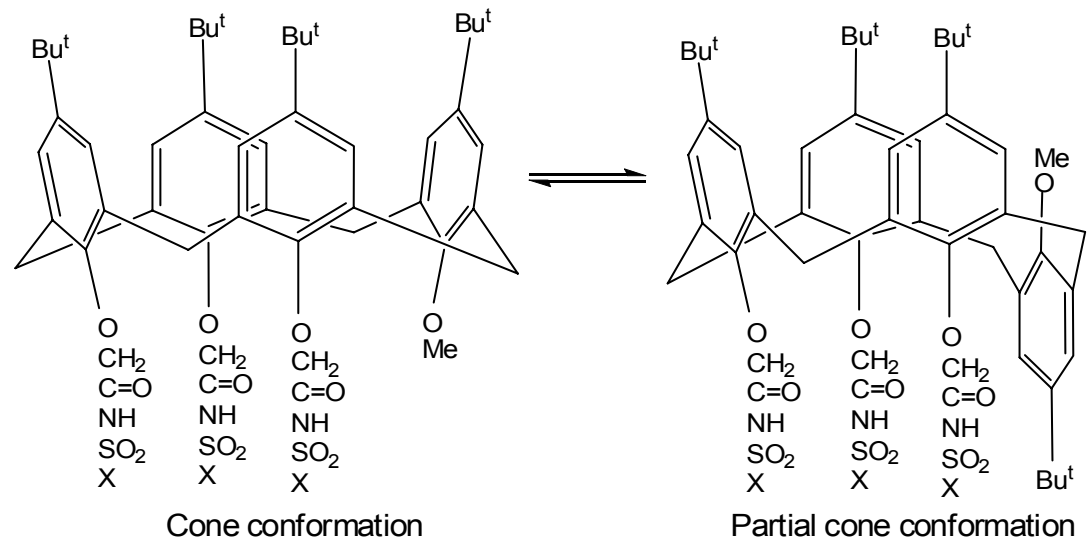

Figure 3. Limiting conformations of tri-ionizable calix[4]arene ligands 5-8.

The ${ }^{1} \mathrm{H}-\mathrm{NMR}$ spectra of ligands 5-8 feature two pairs of doublets for the methylene groups that bridge the arene units $\left(\mathrm{ArCH}_{2} \mathrm{Ar}\right.$ ) (in 7 at 3.20 and $3.33 \mathrm{ppm}$ for the pseudo equatorial protons and 4.11 and $4.29 \mathrm{ppm}$ for the pseudoaxial protons). A pair of doublets for the diastereotopic protons in the two equivalent $\mathrm{OCH}_{2} \mathrm{C}(\mathrm{O})$ groups (in 7 at 4.47 and $4.58 \mathrm{ppm}$ ) and a singlet for the nonequivalent $\mathrm{OCH}_{2} \mathrm{C}(\mathrm{O})$ group (in 7 at $4.56 \mathrm{ppm}$ ) are also observable. Two nonequivalent $\mathrm{N}-\mathrm{H}$ groups appears as a pair of broad singlets at 9.60-10.00 ppm, except for compound 8 due to the stronger acidic character when $\mathrm{X}=\mathrm{SO}_{2} \mathrm{CF}_{3}$.

The new tri-ionizable calix[4]arenes are conformationally flexible. When the ${ }^{1} \mathrm{H}-\mathrm{NMR}$ spectrum of compound 6 was taken in $\mathrm{CDCl}_{3}$ at $23{ }^{\circ} \mathrm{C}$, no signal was observed for the $\mathrm{OCH}_{3}$ protons. When the temperature was increased to $45{ }^{\circ} \mathrm{C}$, a broad peak at $3.53 \mathrm{ppm}$ was seen. When the temperature was equal to or below $0{ }^{\circ} \mathrm{C}$, a broad peak emerged at $3.76 \mathrm{ppm}$. This behavior is interpreted in terms of a cone conformation that interconverts to a partial cone conformation slowly on the NMR time scale at lower temperature but rapidly at higher temperature. The resonances arising from the bridge methylene protons appear as two pairs of doublets at $45{ }^{\circ} \mathrm{C}$ in the region of 3.00-4.50 ppm. The higher field pair of doublets corresponds to the pseudo-equatorial protons (closer to aromatic rings) and the lower field pair of doublets to the pseudo-axial protons (closer to the ether linkage). The closest pseudo-equatorial protons to the $\mathrm{OCH}_{3}$ group are strongly affected by variations in temperature. At $45^{\circ} \mathrm{C}$, they appeared as a sharp doublet at $3.24 \mathrm{ppm}$, but when the temperature was decreased the peaks become broader and almost collapse into the other pseudo-equatorial protons peak at $-20{ }^{\circ} \mathrm{C}$. This is explained in terms of the conformationally mobile character of the aromatic ring holding the $\mathrm{OCH}_{3}$ group in compound 6.

\section{Complexation of trivalent lanthanides}

Since the new ligands 5-8 (Figure 2) behave as acidic ligands $\left(\mathrm{LH}_{3}\right)$, the first estimation of their binding properties towards some lanthanide ions was obtained potentiometrically. Stability constants $\beta_{\mathrm{xyz}}$ of the complexes, corresponding to the overall equationx $\mathrm{Ln}^{3+}+\mathrm{YL}^{3-}+\mathrm{zH}^{+} \leftrightarrow$ 
$\mathrm{Ln}_{\mathrm{x}} \mathrm{L}_{\mathrm{y}} \mathrm{H}_{\mathrm{z}}{ }^{(3 \mathrm{x}-3 \mathrm{y}+\mathrm{z})+}(1)$ were determined in $\mathrm{MeOH}$ in the presence of $10^{-2} \mathrm{M} \mathrm{Et}_{4} \mathrm{NCl}$ as the background electrolyte using a competitive method with the protons. The experimental procedure has been previously described in detail. ${ }^{15}$

In a first step, the acid-base behavior of ligands 5-8 was investigated. Interpretation of the titration curves for ligands 5-7 (Figure 4) confirmed their tri-acidic character leading to the values of the ionization constants, $\mathrm{pK}_{\mathrm{a}, \mathrm{n}}$, given in Table 1 . The $\mathrm{pK}_{\mathrm{a}, \mathrm{n}}$ values for ligands $\mathbf{5}$ and $\mathbf{6}$ are nearly the same due to the similarity of the electron-withdrawing abilities of the $\mathrm{X}$ groups in the $\mathrm{OCH}_{2} \mathrm{C}(\mathrm{O}) \mathrm{NHSO}_{2} \mathrm{X}$ side arms. ${ }^{16}$ Due to stronger electron-withdrawal when $\mathrm{X}=\mathrm{C}_{6} \mathrm{H}_{4}-4-\mathrm{NO}_{2}$ than $\mathrm{Me}$ and $\mathrm{Ph}$, the $\mathrm{pK}_{\mathrm{a}, \mathrm{n}}$ values shift appreciably lower. Ligand $\mathbf{8}$ behaved quite differently. The titration curve showed a drop of potential (i.e., an increase in $\mathrm{pH}$ ) from the beginning with no inflexion points. We are unable to interpret this behavior at present.

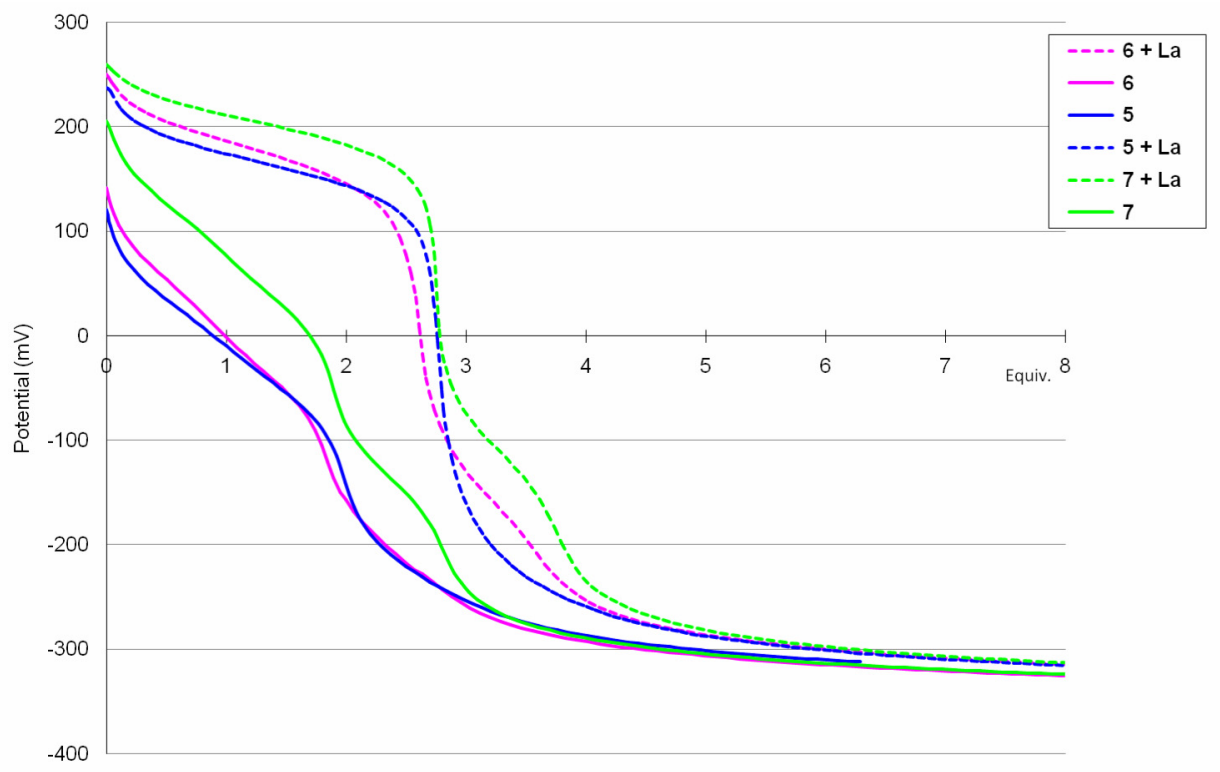

Figure 4. Potentiometric titration curves for ligands 5-7 in $\mathrm{MeOH}$ in the absence and presence of $\mathrm{La}^{3+}$

Titration curves for ligand 5 in the presence of one equivalent of $\mathrm{La}^{3+}, \mathrm{Eu}^{3+}$ and $\mathrm{Yb}^{3+}$ (Figure 5) and of the three ligands 5-7 in the presence of $\mathrm{La}^{3+}$ (Figure 4) showed equivalence points near three equivalents of base, consistent with the participation of the three $N$-(X)sulfonyl carboxamide groups to the complexation and the formation of 1:1 (Ln:L) complexes and possibly the corresponding protonated species. After these equivalences, the shape of the titration curves suggested the formation of methoxy species. The simplest models fitting satisfactorily the experimental data are given in Table 2 . However, it must be said that certainly additional methoxy species should form besides the $\operatorname{LnL}(\mathrm{MeO})^{-}$complex, since the fit in this region still has to be improved. The results show no important selectivity of ligand $\mathbf{5}$ in the series. Lanthanum complexes with ligand $\mathbf{7}$ are the least stable. This is in agreement with the acidity of 
this ligand, as shown by linear correlation between $\log \beta_{110}$ and $\Sigma\left(\mathrm{pK}_{\mathrm{a}, \mathrm{n}}\right)$ (Figure 6) and confirms the predominance of electrostatic interactions in the stability of these complexes.

Table 1. Values of $\mathrm{pK}_{\mathrm{a}, \mathrm{n}}$ for ligands 5-7 in $\mathrm{MeOH}$ at $25^{\circ} \mathrm{C}$

\begin{tabular}{|c|c|c|c|}
\hline \multicolumn{4}{|c|}{ Ligand } \\
\hline $\mathrm{n}$ & 5 & 6 & 7 \\
\hline 1 & $8.00 \pm 0.01^{\mathrm{a}}$ & $7.80 \pm 0.06$ & $6.49 \pm 0.01$ \\
\hline 2 & $9.70 \pm 0.06$ & $9.85 \pm 0.08$ & $8.36 \pm 0.01$ \\
\hline 3 & $13.3 \pm 0.2$ & $13.0 \pm 0.1$ & $11.59 \pm 0.03$ \\
\hline
\end{tabular}

${ }^{\mathrm{a}}$ Confidence intervals: $\pm \sigma_{\mathrm{n}-1}$, with $\sigma_{\mathrm{n}-1}$ being the standard deviation on mean values of $\mathrm{n}$ experiments $(\mathrm{n} \geq 3)$.

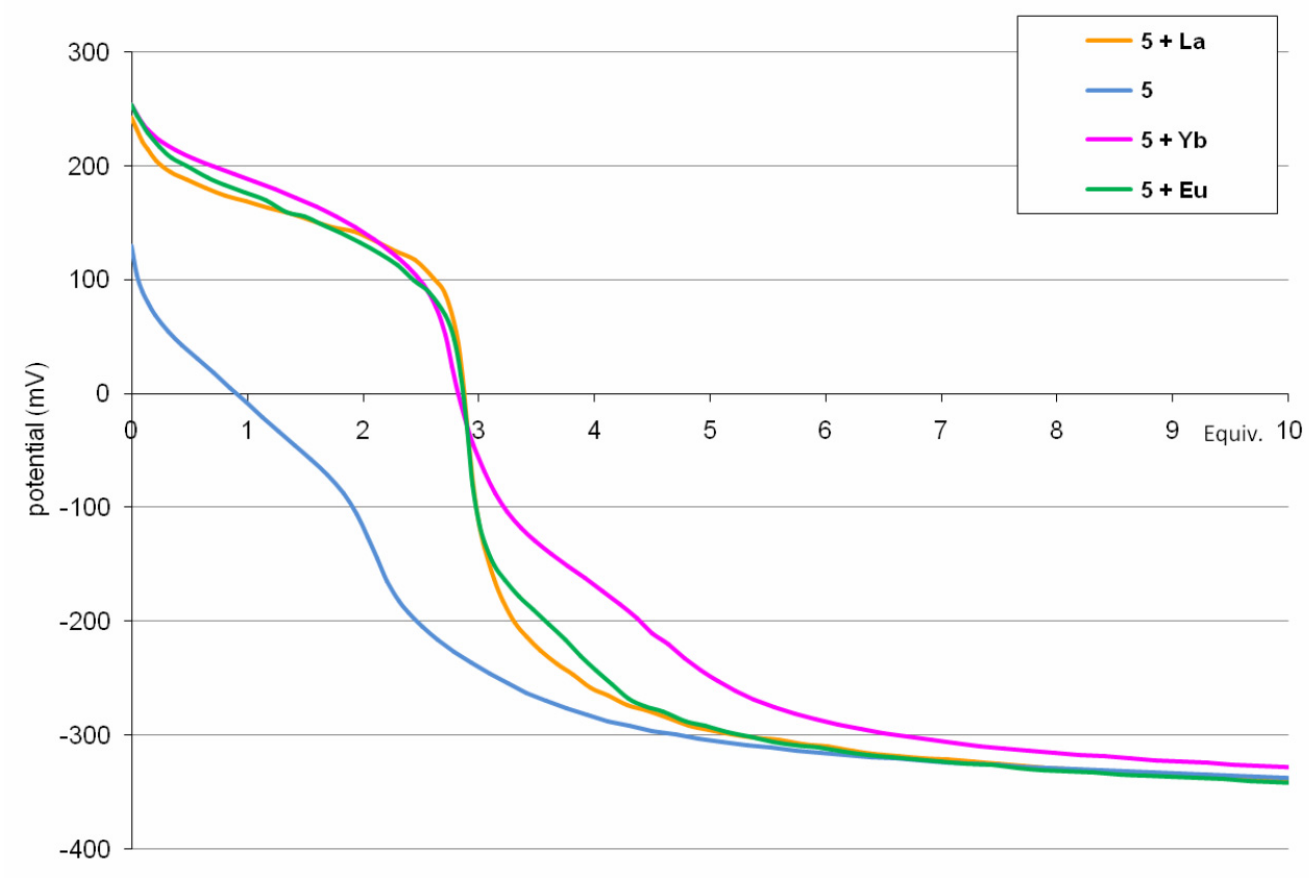

Figure 5. Potentiometric titration curves corresponding to the complexation of $\mathrm{La}^{3+}, \mathrm{Eu}^{3+}$, and $\mathrm{Yb}^{3+}$ by ligand 5 in $\mathrm{MeOH}$. 
Table 2. Overall stability constants of some lanthanide complexes in $\mathrm{MeOH}$ at $25^{\circ} \mathrm{C}$

\begin{tabular}{|c|c|c|c|c|c|}
\hline \multicolumn{6}{|c|}{$\log \beta_{\mathrm{xyz} \pm \sigma n-1}$ for ligand } \\
\hline cation & xyz & species & 5 & 6 & 7 \\
\hline \multirow[t]{4}{*}{$\mathrm{La}^{3+}$} & 110 & $\mathrm{LnL}$ & $15.6 \pm 0.2$ & $14.9 \pm 0.3$ & $13.0 \pm 0.1$ \\
\hline & 111 & $\mathrm{LnLH}^{+}$ & $22.27 \pm 0.02$ & $22.03 \pm 0.03$ & $19.0 \pm 0.2$ \\
\hline & & $\mathrm{LnLH}_{2}{ }^{2+}$ & $27.1 \pm 0.2$ & - & - \\
\hline & $11-1$ & $\mathrm{LnL}(\mathrm{OMe})^{-}$ & $2.8 \pm 0.3$ & $3.2 \pm 0.5$ & $2.3 \pm 0.1$ \\
\hline \multirow[t]{4}{*}{$\mathrm{Eu}^{3+}$} & 110 & $\mathrm{LnL}$ & $16.2 \pm 0.3$ & & \\
\hline & 111 & $\mathrm{LnLH}^{+}$ & $22.9 \pm 0.2$ & & \\
\hline & & $\mathrm{LnLH}_{2}{ }^{2+}$ & $28.1 \pm 0.2$ & & \\
\hline & $11-1$ & $\mathrm{LnL}(\mathrm{OMe})^{-}$ & $4.3 \pm 0.4$ & & \\
\hline \multirow[t]{4}{*}{$\mathrm{Yb}^{3+}$} & 110 & $\mathrm{LnL}$ & $15.62 \pm 0.01$ & & \\
\hline & 111 & $\mathrm{LnLH}^{+}$ & $22.87 \pm 0.01$ & & \\
\hline & & $\mathrm{LnLH}_{2}{ }^{2+}$ & $27.1 \pm 0.1$ & & \\
\hline & $11-1$ & $\mathrm{LnL}(\mathrm{OMe})^{-}$ & $4.65 \pm 0.01$ & & \\
\hline
\end{tabular}

${ }^{a}$ Confidence intervals: $\pm \sigma_{\mathrm{n}-1}$, with $\sigma_{\mathrm{n}-1}$ being the standard deviation on mean values of $\mathrm{n}$ experiments $(\mathrm{n} \geq 3)$.

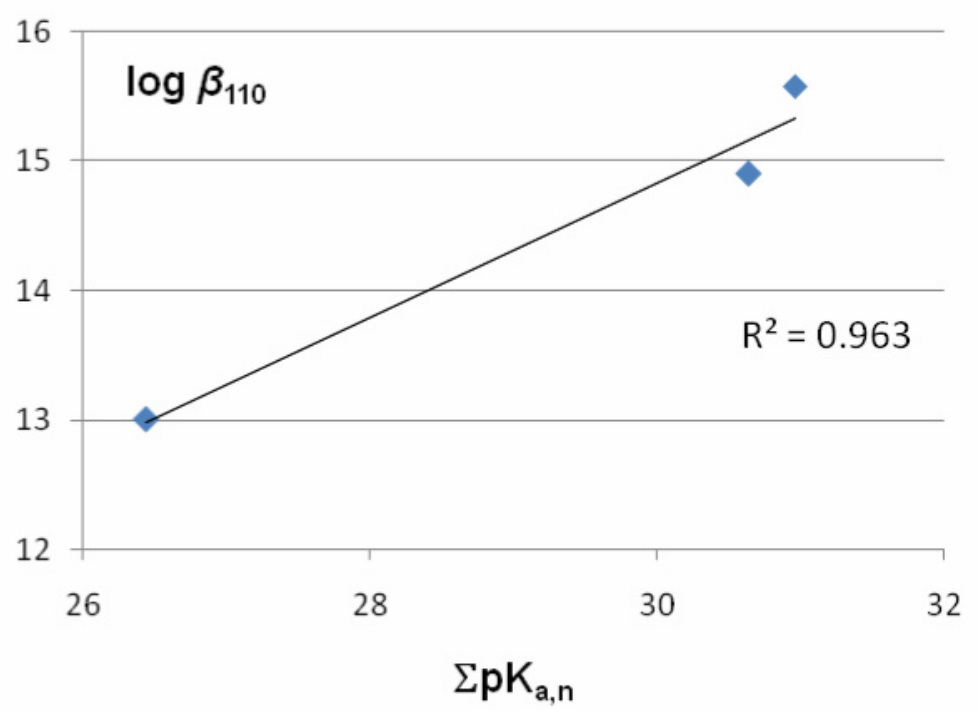

Figure 6. Plot of $\log \beta_{110}\left(\mathrm{La}^{3+}\right)$ versus $\Sigma \mathrm{pK}_{\mathrm{a}, \mathrm{n}}$ for ligands 5-7.

\section{Experimental Section}

General. Reagents were purchased from commercial suppliers and used as received unless otherwise indicated. Tetrahydrofuran (THF) was dried over sodium with benzophenone as an 
indicator and distilled immediately before use. Dimethylformamide (DMF), benzene, and acetonitrile were stored over $4 \AA$ molecular sieves. Potassium carbonate and cesium fluoride were activated by heating at $120{ }^{\circ} \mathrm{C}$ under oil pump vacuum overnight just before use. Melting points were determined with a Mel-Temp melting point apparatus. Infrared (IR) spectra were recorded with a Perkin-Elmer Model 1600 FT-IR spectrometer on a $\mathrm{NaCl}$ plate (film deposited from $\mathrm{CH}_{2} \mathrm{Cl}_{2}$ solution) and are reported in wavenumbers $\left(\mathrm{cm}^{-1}\right) .{ }^{1} \mathrm{H}$ and ${ }^{13} \mathrm{C} \mathrm{NMR}$ spectra were recorded with a Varian Unity Inova FT-500 spectrometer at 499.7 and $125.7 \mathrm{MHz}$, respectively, in $\mathrm{CDCl}_{3}$. The ${ }^{1} \mathrm{H}-\mathrm{NMR}$ chemical shifts $(\delta)$ are reported in parts per million (ppm) downfield from tetramethylsilane (TMS). Splitting patterns in the NMR spectra are identified as: s, singlet; $\mathrm{d}$, doublet; dd, doublet of doublets; t, triplet; q, quartet; br s, broad singlet; and m, multiplet. Elemental analysis was performed by Desert Analytics Laboratory (now Columbia Analytical Services) of Tucson, Arizona.

Synthesis of 5,11,17,23-tetrakis(1,1-dimethylethyl)-28-methoxycalix[4]arene (10). To a solution of CsF (0.18 g, $1.2 \mathrm{mmol})$ in DMF (20 mL) was added p-tert-butylcalix[4]arene (9; toluene complex 1:0.8, $0.72 \mathrm{~g}, 1.0 \mathrm{mmol})^{17}$ and $\mathrm{MeI}(0.62 \mathrm{~mL}, 10 \mathrm{mmol})$. The mixture was stirred at $40{ }^{0} \mathrm{C}$ for $26 \mathrm{~h}$ and then quenched by addition of $2 \mathrm{~N} \mathrm{HCl}(40 \mathrm{~mL})$. The mixture was extracted with $\mathrm{CH}_{2} \mathrm{Cl}_{2}(2 \times 20 \mathrm{~mL})$. The combined organic layers were washed with water $(2 \mathrm{x}$ $25 \mathrm{~mL}$ ) and dried over $\mathrm{MgSO}_{4}$. After evaporation of the solvent in vacuo, the residue was treated with $\mathrm{MeOH}(20 \mathrm{~mL})$ and $\mathrm{CH}_{2} \mathrm{Cl}_{2}(20 \mathrm{~mL})$. The solution was filtered to remove unreacted $p$-tertbutylcalix[4]arene. The filtrate was evaporated in vacuo and chromatographed on silica gel with $\mathrm{CH}_{2} \mathrm{Cl}_{2}$ /petroleum ether (3:1) as eluent to give $0.40 \mathrm{~g}(60 \%)$ of $2: \mathrm{mp} 206-208{ }^{\circ} \mathrm{C}\left(\mathrm{lit}^{13} 203-204\right.$ ${ }^{\circ} \mathrm{C}$ ). IR (deposit on $\mathrm{NaCl}$ plate from $\mathrm{CH}_{2} \mathrm{Cl}_{2}$ solution): $3325,3212,3189(\mathrm{OH}), 1261(\mathrm{C}-\mathrm{O}) \mathrm{cm}^{-1}$. ${ }^{1} \mathrm{H}$ NMR (500 MHz, $\mathrm{CDCl}_{3}$ ): $\delta$ 1.16-1.25 (m, 36H), $3.43(\mathrm{~d}, 4 \mathrm{H}, J 13.0 \mathrm{~Hz}), 4.12(\mathrm{~s}, 3 \mathrm{H}), 4.27$ $(\mathrm{d}, 2 \mathrm{H}, J 14.0 \mathrm{~Hz}), 4.36(\mathrm{~d}, 2 \mathrm{H}, J 13.0 \mathrm{~Hz}), 6.99$ (d, 2H, J 2.5 Hz), 7.02-7.03 (m, 4H), 7.10 (s, 2H), 9.55 (s, 2H), $10.16(\mathrm{~s}, 1 \mathrm{H})$.

Synthesis of 5,11,17,23-tetrakis(1,1-dimethylethyl)-25,26,27-tris(ethoxycarbonylmethoxy)28-methoxycalix[4]arene (11). To $10(0.25 \mathrm{~g}, 0.38 \mathrm{mmol})$ in $\mathrm{MeCN}(30 \mathrm{~mL})$ was added $\mathrm{K}_{2} \mathrm{CO}_{3}$ $(0.83 \mathrm{~g}, 6.0 \mathrm{mmol})$ and ethyl bromoacetate $(0.51 \mathrm{~mL}, 4.6 \mathrm{mmol})$. The mixture was refluxed for 6 $\mathrm{h}$ and the solvent was removed in vacuo. To the solid residue were added $\mathrm{CH}_{2} \mathrm{Cl}_{2}(50 \mathrm{~mL})$ and 2 $\mathrm{N} \mathrm{HCl}(50 \mathrm{~mL})$. The organic phase was separated, extracted with water $(2 \times 50 \mathrm{~mL})$, and dried over $\mathrm{MgSO}_{4}$. After evaporation in vacuo, the residue was recrystallized from $\mathrm{EtOH}$ to give 0.17 $\mathrm{g}\left(50 \%\right.$ ) of triester 11: $\mathrm{mp} 167-170{ }^{\circ} \mathrm{C}\left(\mathrm{lit}^{14} 171-172{ }^{\circ} \mathrm{C}\right.$ ). IR (deposit on $\mathrm{NaCl}$ plate from $\mathrm{CH}_{2} \mathrm{Cl}_{2}$ solution): 1758, $1741(\mathrm{C}=\mathrm{O}), 1182(\mathrm{C}-\mathrm{O}) \mathrm{cm}^{-1} .{ }^{1} \mathrm{H}$ NMR $\left(500 \mathrm{MHz}, \mathrm{CDCl}_{3}\right): \delta 0.86(\mathrm{br} \mathrm{s}, 18 \mathrm{H})$, 1.22-1.36 (m, $27 \mathrm{H}), 3.20$ (m, 4H), 3.90-5.15 (m, 19H), 6.52 (m, 4H, 7.06 (br s, 4H).

Synthesis of 5,11,17,23-tetrakis(1,1-dimethylethyl)-26,27,28-tris(hydroxycarbonylmethoxy)-25-methoxycalix[4]arene (12). To triester 11 (1.68 g, $1.83 \mathrm{mmol})$ in THF (75 mL) was added $\mathrm{Me}_{4} \mathrm{NOH}(80 \mathrm{~mL}$ of $7.8 \%$ aq solution) and the mixture was refluxed for $30 \mathrm{~h}$. The THF was evaporated in vacuo and the residue was acidified to $\mathrm{pH}<1$ ( $8 \mathrm{~mL}$ of conc $\mathrm{HCl})$. After extraction with $\mathrm{CH}_{2} \mathrm{Cl}_{2}(75 \mathrm{~mL})$, the aqueous phase was back-extracted with $\mathrm{CH}_{2} \mathrm{Cl}_{2}(25 \mathrm{~mL})$. 
The combined organic extracts were washed with water $(50 \mathrm{~mL})$ and dried over $\mathrm{MgSO}_{4}$. Evaporation in vacuo gave $1.22 \mathrm{~g}(80 \%)$ of 12 as a white solid: $\mathrm{mp} 248-251{ }^{\circ} \mathrm{C}\left(\right.$ lit $^{14} 243-245$ ${ }^{0} \mathrm{C}$ ). IR (deposit on $\mathrm{NaCl}$ plate from $\mathrm{CH}_{2} \mathrm{Cl}_{2}$ solution): 2800-3600 $(\mathrm{OH}), 1751(\mathrm{C}=\mathrm{O}), 1194(\mathrm{C}$ O) $\mathrm{cm}^{-1} .{ }^{1} \mathrm{H}$ NMR $\left(500 \mathrm{MHz}, \mathrm{CDCl}_{3}\right): \delta 0.86(\mathrm{~s}, 9 \mathrm{H}), 0.87(\mathrm{~s}, 9 \mathrm{H}), 1.32(\mathrm{~s}, 18 \mathrm{H}), 3.25(\mathrm{dd}, 4 \mathrm{H}, J$ $13.0 \mathrm{~Hz}), 3.80$ (s, 3H), 4.28 (d, 2H, J $13.0 \mathrm{~Hz}), 4.56$ (br s, 2H), 4.81 (br s, 6H), 6.63 (d, 4H, $12.0 \mathrm{~Hz}), 7.15(\mathrm{~s}, 4 \mathrm{H})$.

Synthesis of 5,11,17,23-tetrakis(1,1-dimethylethyl)-26,27,28-tris(chloridocarbonylmethoxy)-25-methoxycalix[4]arene (13). To triacid $12(1.20 \mathrm{~g}, 1.44 \mathrm{mmol})$ in benzene (40 $\mathrm{mL})$ under nitrogen in an oil bath at $60{ }^{0} \mathrm{C}$, oxalyl chloride $(0.77 \mathrm{~mL}, 6 \mathrm{eq})$ was added. The mixture was stirred at $60{ }^{0} \mathrm{C}$ for $17 \mathrm{~h}$. The solution was evaporated in vacuo and $1.28 \mathrm{~g}(100 \%)$ of a waxy solid was obtained. IR (deposit on $\mathrm{NaCl}$ plate from $\mathrm{CH}_{2} \mathrm{Cl}_{2}$ solution): $1807(\mathrm{C}=\mathrm{O}) \mathrm{cm}^{-1}$.

Synthesis of 5,11,17,23-tetrakis(1,1-dimethylethyl)-26,27,28-tris[ $N$-(X)sulphonyl carboxamidomethoxy]-25-methoxycalix[4]arenes (5-8). The sulfonamide salt was prepared under argon by adding THF $(20 \mathrm{~mL})$ to a flask containing $\mathrm{NaH}(0.41 \mathrm{~g}, 17.08 \mathrm{mmol})$. A solution of the appropriate sulfonamide $(7.20 \mathrm{mmol})$ in THF $(40 \mathrm{~mL})$ was added over a 10 -min period. The mixture was stirred at room temperature for 1.5 hour followed by the dropwise addition of a solution of the tri(acid chloride) $13(1.30 \mathrm{~g}, 1.44 \mathrm{mmol})$ in THF $(20 \mathrm{~mL})$. The mixture was stirred at room temperature for $14 \mathrm{~h}$. Water $(5.0 \mathrm{~mL})$ was added slowly to destroy the residual $\mathrm{NaH}$. The organic phase was washed with $10 \%$ aq $\mathrm{K}_{2} \mathrm{CO}_{3}(2 \times 40 \mathrm{~mL})$. The solvent was evaporated in vacuo. The residue was dissolved in $\mathrm{MeOH}-\mathrm{CH}_{2} \mathrm{Cl}_{2}$ (1:9) and chromatographed on silica gel with $\mathrm{MeOH}-\mathrm{CH}_{2} \mathrm{Cl}_{2}$ (1:9) as eluent. The resultant solid was dissolved in $\mathrm{CH}_{2} \mathrm{Cl}_{2}(10$ $\mathrm{mL})$ and washed with $1 \mathrm{M} \mathrm{HCl}(10 \mathrm{~mL})$ and distilled water $(10 \mathrm{~mL})$. The organic solution was dried over $\mathrm{MgSO}_{4}$ and evaporated in vacuo.

\section{5,11,17,23-Tetrakis(1,1-dimethylethyl)-26,27,28-tris( $N$-methanesulfonyl}

carboxamidomethoxy)-25-methoxycalix[4]arene (5) was obtained as $0.85 \mathrm{~g}$ (55 \%) of white solid: mp 287$290{ }^{\circ} \mathrm{C}$. IR (deposit on $\mathrm{NaCl}$ plate from $\mathrm{CH}_{2} \mathrm{Cl}_{2}$ solution): $3240(\mathrm{~N}-\mathrm{H}), 1720(\mathrm{C}=\mathrm{O}), 1348,1185$ $\left(\mathrm{SO}_{2}\right) \mathrm{cm}^{-1} .{ }^{1} \mathrm{H}-\mathrm{NMR}\left(500 \mathrm{MHz}, \mathrm{CDCl}_{3}\right): \delta 1.02(\mathrm{~s}, 18 \mathrm{H}), 1.10(\mathrm{~s}, 9 \mathrm{H}), 1.16(\mathrm{~s}, 9 \mathrm{H}), 3.34(\mathrm{~d}, 2 \mathrm{H}$, $J 13.0 \mathrm{~Hz}), 3.38-3.44(\mathrm{~m}, 14 \mathrm{H}), 4.17(\mathrm{~d}, 2 \mathrm{H}, J 13.0 \mathrm{~Hz}), 4.47$ (d, 2H, J 13.0 Hz), 4.54 (d, 2H, $15.0 \mathrm{~Hz}), 4.61(\mathrm{~s}, 2 \mathrm{H}), 4.67(\mathrm{~d}, 2 \mathrm{H}, J 15.5 \mathrm{~Hz}), 6.79(\mathrm{~s}, 2 \mathrm{H}) 6.85(\mathrm{~s}, 2 \mathrm{H}), 6.94(\mathrm{br} \mathrm{s}, 2 \mathrm{H}), 6.96$ (br s, 2H), 9.70 (br s, 2H), 9.75 (br s, $1 \mathrm{H}) .{ }^{13} \mathrm{C} \mathrm{NMR} \mathrm{(500} \mathrm{MHz,} \mathrm{CDCl}_{3}$ ): $\delta 30.7,31.0,32.0,32.2$, 32.3, 33.1, 35.2, 35.3, 54.4, 74.0, 74.2, 125.4, 125.8, 125.9, 126.2, 131.7, 132.2, 133.4, 134.1, 145.1, 147.8, 147.8, 152.2, 152.6, 168.2, 168.3. Anal. Calcd. for $\mathrm{C}_{54} \mathrm{H}_{73} \mathrm{~N}_{3} \mathrm{O}_{13} \mathrm{~S}_{3}$ : C, 60.74; $\mathrm{H}$, 6.84 ; N, 3.94; Found C, 60.50; H, 7.01; N, 3.86.

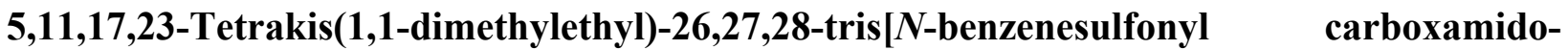
methoxy]-25-methoxycalix[4]arene (6) was realized as $1.19 \mathrm{~g}(65 \%)$ of white solid: $\mathrm{mp} 256-$ $258{ }^{\circ} \mathrm{C}$. IR (deposit on $\mathrm{NaCl}$ plate from $\mathrm{CH}_{2} \mathrm{Cl}_{2}$ solution): $3240(\mathrm{~N}-\mathrm{H}), 1720(\mathrm{C}=\mathrm{O}), 1348,1186$ $\left(\mathrm{SO}_{2}\right) \mathrm{cm}^{-1} .{ }^{1} \mathrm{H}-\mathrm{NMR}\left(500 \mathrm{MHz}, \mathrm{CDCl}_{3}\right): \delta 0.96(\mathrm{~s}, 18 \mathrm{H}) 1.16(\mathrm{~s}, 9 \mathrm{H}), 1.20(\mathrm{~s}, 9 \mathrm{H}), 3.13(\mathrm{~d}, 2 \mathrm{H}$, $J 13.0 \mathrm{~Hz}$ ), 3.24 (br d, 2H, $J 12.5 \mathrm{~Hz}$ ), 3.52 (br s, 3H), 4.08 (d, 2H, $J 13.0 \mathrm{~Hz}$ ), 4.21 (d, 2H, $J$ $13.0 \mathrm{~Hz}), 4.30-4.42(\mathrm{~m}, 4 \mathrm{H}), 4.58(\mathrm{~s}, 2 \mathrm{H}), 6.63$ (br s, 2H), 6.65 (br s, 2H), $6.88(\mathrm{~s}, 2 \mathrm{H}), 6.95$ (s, 2H), $7.50(\mathrm{t}, 2 \mathrm{H}, J 7.5 \mathrm{~Hz}), 7.55(\mathrm{t}, 4 \mathrm{H}, J 7.5 \mathrm{~Hz}), 7.59-7.67(\mathrm{~m}, 3 \mathrm{H}), 8.03$ (d, 2H, J 8.0 Hz), 8.17 
$(\mathrm{d}, 4 \mathrm{H}, J 8.0 \mathrm{~Hz}), 9.68(\mathrm{~s}, 2 \mathrm{H}), 9.75(\mathrm{~s}, 1 \mathrm{H}) .{ }^{13} \mathrm{C} \mathrm{NMR}\left(500 \mathrm{MHz}, \mathrm{CDCl}_{3}\right): \delta 31.1,31.4,31.4$, $33.8,34.0,34.1,53.4,73.8,74.0,125.4,125.8,125.9,126.2,128.6,128.7,129.0,129.1,131.5$, 132.1, 133.0, 133.7, 134.1, 134.1, 138.3, 138.4, 145.8, 146.2, 146.6, 151.9, 152.5, 167.6, 168.2. Anal. Calcd. for $\mathrm{C}_{69} \mathrm{H}_{79} \mathrm{~N}_{3} \mathrm{O}_{13} \mathrm{~S}_{3}$ : C, 66.06; H, 6.35; N, 3.35; Found C, 66.37; H, 6.15; N, 3.44.

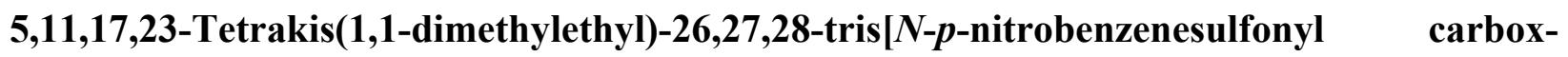
amidomethoxy]-25-methoxycalix[4]arene (7) was obtained as $1.31 \mathrm{~g}$ (65\%) of white solid: $\mathrm{mp}$ 186-189 ${ }^{\circ} \mathrm{C}$. IR (deposit on $\mathrm{NaCl}$ plate from $\mathrm{CH}_{2} \mathrm{Cl}_{2}$ solution): $3259(\mathrm{~N}-\mathrm{H}), 1720(\mathrm{C}=\mathrm{O}), 1348$, $1162\left(\mathrm{SO}_{2}\right) \mathrm{cm}^{-1} .{ }^{1} \mathrm{H}-\mathrm{NMR}\left(500 \mathrm{MHz}, \mathrm{CDCl}_{3}\right): \delta 1.07(\mathrm{~s}, 18 \mathrm{H}), 1.12(\mathrm{~s}, 18 \mathrm{H}), 3.20(\mathrm{~d}, 2 \mathrm{H}, J 13.0$ $\mathrm{Hz}), 3.33$ (d, 2H, J 13.5 Hz), 3.52 (br s, 3H), 4.11 (d, 2H, J 13.5 Hz), 4.29 (d, 2H, J $13.0 \mathrm{~Hz}$ ), 4.47 (d, 2H, J $15.5 \mathrm{~Hz}), 4.56(\mathrm{~s}, 2 \mathrm{H}), 4.58$ (d, 2H, J $15.0 \mathrm{~Hz}), 6.77-6.81(\mathrm{~m}, 4 \mathrm{H}), 6.83$ (d, 2H, $2.0 \mathrm{~Hz}), 6.86$ (s, 2H), 8.29 (d, 2H, J 9.0 Hz), 8.32 (d, 4H, J 9.0 Hz), 8.34-8.42 (m, 6H), 9.91 (s, 2H), $9.96(\mathrm{~s}, 1 \mathrm{H}) .{ }^{13} \mathrm{C} \mathrm{NMR}\left(500 \mathrm{MHz}, \mathrm{CDCl}_{3}\right): \delta 31.6,32.0,32.5,33.1,33.6,34.1,53.3,73.8$, 75.0, 125.3, 125.4, 125.8, 125.9, 128.8, 129.7, 131.0, 132.1, 133.8, 133.0, 133.6, 135.6, 135.9, 144.7, 145.0, 145.8 146.8, 152.0, 152.2, 167.5, 167.8. Anal. Calcd. for $\mathrm{C}_{69} \mathrm{H}_{76} \mathrm{~N}_{6} \mathrm{O}_{19} \mathrm{~S}_{3}: \mathrm{C}, 59.67$; H, 5.47; N, 6.05; Found C, 59.88; H, 5.48; N, 5.95.

\section{$\mathbf{5 , 1 1 , 1 7 , 2 3 - T e t r a k i s ( 1 , 1 - d i m e t h y l e t h y l ) - 2 6 , 2 7 , 2 8 - t r i s [} \boldsymbol{N}$-trifluoromethanesulfonyl}

carboxamidomethoxy]-25-methoxycalix[4]arene (8) was obtained as $0.93 \mathrm{~g}(52 \%)$ of white solid: mp 317-320 ${ }^{\circ} \mathrm{C}$. IR (deposit on $\mathrm{NaCl}$ plate from $\mathrm{CH}_{2} \mathrm{Cl}_{2}$ solution): $1615\left(\mathrm{C}(\mathrm{O}) \mathrm{N}^{-}\right), 1311$, $1190\left(\mathrm{SO}_{2}\right) \mathrm{cm}^{-1} .{ }^{1} \mathrm{H}-\mathrm{NMR}\left(500 \mathrm{MHz}, \mathrm{CDCl}_{3}\right): \delta 1.11(\mathrm{~s}, 9 \mathrm{H}), 1.14(\mathrm{~s}, 9 \mathrm{H}), 1.16(\mathrm{~s}, 18 \mathrm{H}), 3.37$ (d, 2H, J $12.5 \mathrm{~Hz}), 3.42$ (d, 2H, J $12.5 \mathrm{~Hz}), 3.87$ (s, 3H), 4.10 (d, 2H, J 12.5 Hz), 4.14 (d, 2H, J $12.5 \mathrm{~Hz}), 4.36(\mathrm{~s}, 2 \mathrm{H}), 4.38(\mathrm{~d}, 2 \mathrm{H}, J 17.0 \mathrm{~Hz}), 4.58$ (d, 2H,J $17.0 \mathrm{~Hz}), 7.09$ (br s, 2H), 7.10 (br $\mathrm{s}, 2 \mathrm{H}), 7.13(\mathrm{~s}, 4 \mathrm{H}) .{ }^{13} \mathrm{C} \mathrm{NMR}\left(500 \mathrm{MHz}, \mathrm{CDCl}_{3}\right): \delta 31.0,31.5,31.6,33.2,33.9,34.5,54.0,73.1$, $73.8,125.3,125.1,125.5,125.9,130.0,132.0,133.8,133.9,146.2,145.9,146.5,151.7,152.9$, 168.0, 168.33. Anal. Calcd. for $\mathrm{C}_{54} \mathrm{H}_{64} \mathrm{~N}_{3} \mathrm{O}_{13} \mathrm{~S}_{3} \mathrm{~F}_{9}$ : C, 52.67; H, 5.20; N, 3.41; Found C, 52.27; H, 5.42; N, 3.09. (Note: Although the IR and NMR spectra were consistent with the ionized form of $\mathbf{8}$, the combustion analysis results agreed with the neutral ligand.)

\section{Potentiometric titrations}

The experiments were performed at $25{ }^{\circ} \mathrm{C}$ with a combination glass electrode (Mettler U402/S7/120) connected to an automatic titrator (Metrohm 716 DMS Titrino) at $25{ }^{\circ} \mathrm{C}$. The standard filling solution (saturated aq $\mathrm{KCl}$ ) of the external reference of the combination glass electrode was replaced by a $10^{-2} \mathrm{M}$ solution of $\mathrm{Et}_{4} \mathrm{NCl}$ in $\mathrm{MeOH}$ saturated in $\mathrm{AgCl}$. The electrode was calibrated by titration of a $1.0 \mathrm{mM}$ solution of $\mathrm{HClO}_{4}$ with a $10 \mathrm{mM}$ solution of $\mathrm{Me}_{4} \mathrm{NOH}$, previously standardized with potassium phthalate. The stability constants of the lanthanide complexes with these ligands were determined by acid-base titration of the $c a$. 1.0 $\mathrm{mM}$ ligand solutions containing one equivalent of the metal cation with a concentrated $\mathrm{Et}_{4} \mathrm{NOH}$ solution. The titration data were interpreted using the programs Sirko ${ }^{18}$ and Hyperquad. ${ }^{19}$ The protonation constants of the $\mathrm{L}^{3-}$ ligands, previously determined from titrations without the metal ions, were held constant during the refinement procedure. The autoprotolysis constant used for the calculations was $\mathrm{pK}_{\mathrm{MeOH}}=16.7 .^{20}$ 
The metal salts were the lanthanide chlorides: $\mathrm{LaCl}_{3} \bullet \mathrm{H}_{2} \mathrm{O}, \mathrm{EuCl}_{3} \bullet \times \mathrm{H}_{2} \mathrm{O}$, and $\mathrm{YbCl}_{3} \bullet \times \mathrm{H}_{2} \mathrm{O}$, dried at room temperature under vacuum before use. Their stock solutions were titrated by complexometry with EDTA using xylenol orange as an indicator.

\section{Acknowledgements}

We thank the Division of Chemical Sciences, Geosciences, and Biosciences of the Office of Basic Energy Sciences of the U.S. Department of Energy (Grant DE-FG02-90ER14416) for support of this research.

\section{References}

1. Gutsche, C. D. Calixarenes, Royal Society of Chemistry: Cambridge, 1989.

2. Vicens, J.; Böhmer, V., Eds., Calixarenes: A Versatile Class of Macrocyclic Compounds, Kluwer: Dordrecht, 1991.

3. Gutsche, C., Calixarenes Revisited, Royal Society of Chemistry, Cambridge, 1998.

4. Lumetta, G. J.; Rogers. R. D.; Gopalan, A. S. Eds., Calixarenes for Separations, ACS Symposium Series 757, American Chemical Society, Washington, DC, 2000.

5. Mandolini, L.; Ungaro, R., Eds., Calixarenes in Action, Imperial College Press: London, 2000.

6. 6.Asfari, Z.; Böhmer, V.; Harrowfield, J.; Vicens, J. Eds., Calixarenes 2001, Kluwer: Dordrecht, 2001.

7. Vicens, J.; Harrowfield, J. Eds., Calixarenes in the Nanoworld, Springer: Dordrecht, 2007.

8. Gutsche, C. D., Calixarenes. An Introduction, RSC Publishing: Cambridge, 2008.

9. Sliwa, W.; Kozlowski, C. Calixarenes and Resorcinarenes. Synthesis, Properties and Applications, Wiley-VCH:Weinheim, 2009.

10. Talanova, G. G.; Hwang, H.-S.; Talanov, V. S.; Bartsch, R. A., J. Chem. Soc., Chem. Commun., 1998, 419.

11. Talanova, G. G.; Hwang, H.-S.; Talanov, V. S.; Bartsch, R. A., J. Chem. Soc., Chem. Commun., 1998, 1329.

12. Huber, V. J.; Ivy, S. N.; Lu, J.; Bartsch, R. A. J. Chem. Soc., Chem. Commun., 1997, 1499.

13. Groenen, L.; Ruel, B.; Casnati, A.; Verboom, W.; Pochini, A.; Ungaro, R.; Reinhoudt, D. Tetrahedron 1991, 47, 8379

14. Arduini, A.; Casnati, A.; Pochini, A.; Ungaro, R. Supramol. Chem. 1993, 1, 235

15. Arnaud-Neu, F.; Cremin, S.; Harris, S. J.; Owens, M.; McKervey, M. A.; Schwing-Weill, M. J.; Schwinte, P.; Walker, A., J. Chem. Soc., Dalton trans. 1997,329.

16. Perrin, D. D.; Dempsey, B.; Serjeant, C. P., $p K_{a}$ Prediction for Organic Acids and Bases Chapman and Hall: London, 1981. 
17. Arduini, A.; Casnati, A., In Macrocycle Synthesis. A Practical Approach, Parker, D., Ed., Oxford University Press: Oxford 1996, pp 147-149.

18. Vetrogon, V. I.; Lukyanienko, N. G.; Schwing-Weill, M. J.; Arnaud-Neu, F. Talanta 1994, 41, 2105.

19. Gans, P.; Sabatini, P.; Vacca, A., Talanta 1996, 43, 1739.

20. Tremillon, B. La chimie en solvent non-aqueux, P.U.F.: Paris, 1971. 